\title{
Investigation of the Effects of Isotretinoin on Spermatogenesis in Balb/c Mice
}

\section{Balb/c Cinsi Farelerde İzotretinoinin Spermatogenez Üzerine Etkilerinin Araştırılması}

\author{
(D) Meltem KUMAŞ11, iD Mukaddes EŞREFOĞLU22
}

${ }^{1}$ Dokuz Eylul University Faculty of Veterinary Medicine, Department of Histology and Embryology, İzmir, Turkey

2Bezmialem Vakıf University Faculty of Medicine, Department of Histology Embryology, İstanbul, Turkey

\begin{abstract}
Objective: It was aimed to investigate the effect of isotretinoin (ISR), a retinoid derivative of vitamin $\mathrm{A}$, on spermatogenesis via follicle-stimulating hormone (FSH), luteinizing hormone ( $\mathrm{LH})$ and testosterone levels.
\end{abstract}

Methods: Twelve male Balb/c mice were divided into two groups: Control and ISR groups. FSH, LH and testosterone levels were biochemically determined by ELISA assay. All statistical analyses were made with SPSS 20.0 (IBM, New York, USA) and graphics were prepared with Graph Pad Prism Version 6.01 (USA). The parametric Student's t-test was applied for comparison among groups. A p value $\leq 0.05$ was accepted as statistically significant.

Results: Mean FSH, LH and testosterone levels were increased in the ISR group when compared to those of control group. The increases in all hormone levels were found statistically significant between the two groups $(\mathrm{p}<0.05)$.

Conclusion: The increase in serum levels of FSH, LH and testosterone of the ISR group compared to the control group suggests that a dose of $40 \mathrm{mg} / \mathrm{kg}$ of ISR may have stimulant effect on spermatogenesis.

Keywords: Isotretinoin, follicle stimulating hormone, testosterone, luteinizing hormone, Balb/c mice

\section{ÖZ}

Amaç: Vitamin A'nın bir retinoid türevi olan izotretinoinin (ISR) spermatogenez üzerindeki etkisinin follikül stimüle edici hormon (FSH), luteinize edici hormon (LH) ve testosteron seviyeleri üzerinden araştırılması amaçlandı.

Yöntemler: Bu çalışma 12 adet Balb/c cinsi 3 aylık erkek fare ile gerçekleştirildi. Deney grupları kontrol $(n=6)$ ve ISR $(n=6)$ olmak üzere ikiye ayrıldı. Serum örneklerinde FSH, LH ve testosteron seviyeleri ELISA yöntemiyle belirlendi. Tüm analizler ve grafikler için SPSS 20,00 (IBM, New York, USA) ve Graph Pad Prism Version 6,01 (USA) programları kullanıldı. İstatistiki karşılaştırılmalarda parametrik student t-testinden yararlanıldı. Anlamlılık seviyesi $\mathrm{p} \leq 0,05$ olarak kabul edildi.

Bulgular: ISR grubunda ortalama FSH, LH ve testosteron seviyelerinde kontrol grubuna göre artış belirlendi. Bu artış her üç hormon için de iki grup arasında istatistiksel açıdan anlamlı bulundu $(\mathrm{p}<0,05)$.

Sonuç: ISR grubunda kontrol grubuna kıyasla serum FSH, LH ve testosteron seviyelerindeki artış, ISR'nin $40 \mathrm{mg} / \mathrm{kg}$ dozunun spermatogenezi uyarıcı bir etkiye sahip olduğunu düşündürdü.

Anahtar Sözcükler: İzotretinoin, follikül stimüle edici hormon, testosteron, luteinize edici hormon, Balb/c fare
Address for Correspondence: Meltem KUMAŞ, Dokuz Eylul University Faculty of Veterinary Medicine, Department of Histology and Embryology, izmir, Turkey

E-mail: kumasmeltem@gmail.com ORCID ID: orcid.org/0000-0001-6903-3212
Received: 16.04 .2018

Accepted: 15.10 .2019

Cite this article as: Kumaş M, Eşrefoğlu M. Investigation of the Effects of Isotretinoin on Spermatogenesis in Balb/c Mice. Bezmialem Science 2020;8(3):246-9. 


\section{Introduction}

Vitamin A, also known as retinol, is stored in cells called lipocyte or Ito cells localized in the perisinusoidal space of the liver (1). It activates retinol, which is inactive in the liver, in the target tissues. Its active form in tissues is called retinoic acid (2). It is known that vitamin $\mathrm{A}$ and retinoic acid have many important functions in the organism such as growth, reproduction, embryogenesis, differentiation and proliferation of cells, and paradoxically high doses have a teratogenic effect (3-5). Gonadotropins, steroid hormones, somatic cells of testis and vitamin A play an important role in the regulation of spermatogenesis (6). Vitamin $A$ is required for fertility and normal spermatogenesis (7). During spermatogenesis, vitamin A is effective in differentiation of type A spermatogonia to type A1 spermatogonia, initiation of meiosis division, release of spermatozoa into the lumen of germinal epithelium of seminiferous tubules and formation of tight connections that participate in the blood testicle barrier (814).

Follicle stimulating hormone (FSH), luteinizing hormone (LH) and testosterone play an important role in the hormonal regulation of spermatogenesis (7). While FSH provides development of spermium from spermatogonium, LH affects Leydig cells and provides testosterone release. The high levels of these hormones in serum indicates that spermatogenesis has begun and continues.

There are studies suggesting that isotretinoin, one of the 5 known isomers of retinoic acid, may have an inductive effect on spermatogenesis depending on the dose $(15,16)$. Based on this information, in our study, we aimed to examine FSH, LH and testosterone levels in serum to evaluate the spermatogenesis stimulating or suppressive effect of $40 \mathrm{mg} / \mathrm{kg}$ dose of isotretinoin in Balb/c mice.

\section{Methods}

\section{Study Groups}

In our study, a total of $12 \mathrm{Balb} / \mathrm{c} 3$-month-old male mice were used, 6 in each group. During the 6 -week experiment, all mice were fed ad libitum.

A dose of $40 \mathrm{mg} / \mathrm{kg}$ ISR (Alfa Aeser, J61666, Massachusetts, USA) dissolved in $0.1 \mathrm{ml}$ of dimethyl sulfoxide (DMSO) + saline solution (SS) was given daily by oral gavage for 6 weeks $(5,17)$. The control groups were administered $0.1 \mathrm{ml} \mathrm{DMSO}+\mathrm{SS}$, the ISR solvent, during the experiment. At the end of the experiment, blood samples were taken from the heart for biochemical analysis under anesthesia administered intraperitoneally with $5 \mathrm{mg} / \mathrm{kg}$ xylazine and $80 \mathrm{mg} / \mathrm{kg}$ ketamine.

Study methods were approved by Bezmialem Vakif University Experimental Animals Local Ethics Committee with decision number 2013-237.

\section{Biochemical Analysis}

Blood samples from the study groups were taken into heparinized tubes by cardiac puncture. Material taken into biochemistry tube was centrifuged at $3000 \mathrm{x} \mathrm{g}$ for 10 minutes. The obtained serum was taken into the Eppendorf tube and kept at $-80^{\circ} \mathrm{C}$ until the measurement day.

Biochemical analyzes were performed on the plate reader (Thermo Scientific Multiskan FC, 2011-06, USA) using Enzyme-Linked Immunosorbent Assay (ELISA) method, using kits suitable for studying mouse serum samples. Levels of testosterone (Catalog No ADI-900065, ENZO Life Sciences, Plymouth, PA), FSH (Catalog No MyBioSource Inc., USA, MBS2507988) and LH (Catalog No MyBioSource Inc., USA, MBS041300) in serum samples were measured and all results were evaluated statistically. All biochemical analyzes were carried out through service procurement.

\section{Statistical Analysis}

The suitability of the normal distribution was determined by the Shapiro-Wilk test. According to this test, since the data with a $\mathrm{p}$ value greater than 0.05 fit the normal distribution, the difference between groups was compared with the student t-test, which was one of the parametric tests. The $\mathrm{p}$ value indicating the significance level was 0.05 in the $95 \%$ confidence interval. Average data of all analysis results were given with standard deviations. In comparisons with a $\mathrm{p}$ value below 0.05 , the difference between the groups was considered statistically significant. All statistical analyzes were done with SPSS 20.0 (IBM, New York, USA) program and graphics were prepared with Graph Pad Prism 6 program.

\section{Results}

The mean testosterone hormone level in the control group was $18.05 \pm 1.01 \mathrm{pg} / \mathrm{mL}$ and this value was found to be $30.05 \pm 1.33$ $\mathrm{pg} / \mathrm{mL}$ in the ISR group. This increase in testosterone level in the ISR group was also statistically significant $(\mathrm{p}=0.004$; Figure 1$)$.

The FSH level was similarly higher in the ISR group $(10.83 \pm 0.26$ $\mathrm{ng} / \mathrm{mL})$ than the control group $(6.41 \pm 0.48 \mathrm{ng} / \mathrm{mL}),(\mathrm{p}=0.002$; Figure 2). A significant increase was observed in the LH level in the ISR group $(7.54 \pm 0.34 \mathrm{mlU} / \mathrm{mL})$ compared to the control group $(4.74 \pm 0.45 \mathrm{mlU} / \mathrm{mL}),(\mathrm{p}=0.002$; Figure 3$)$.

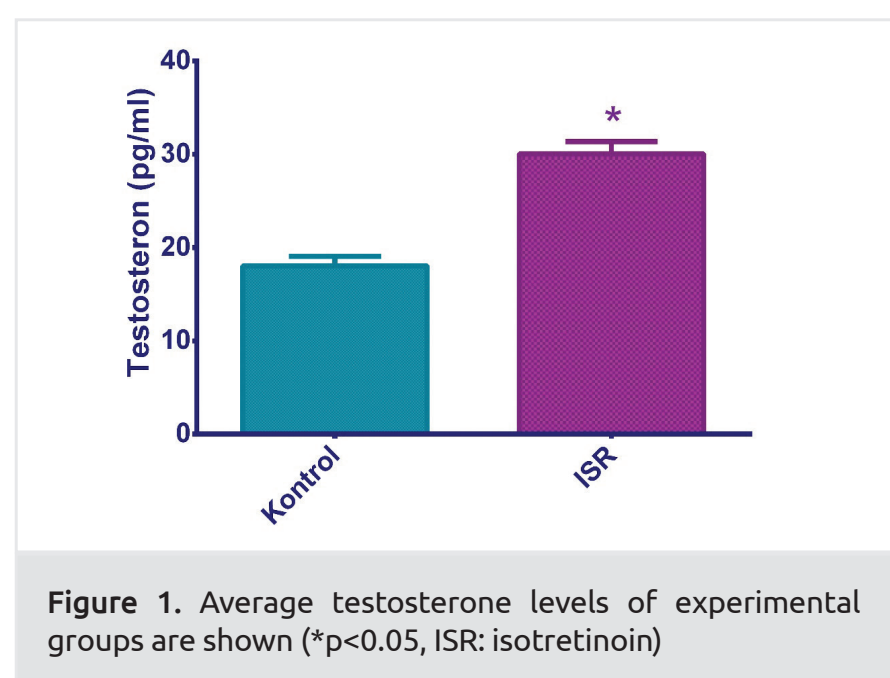




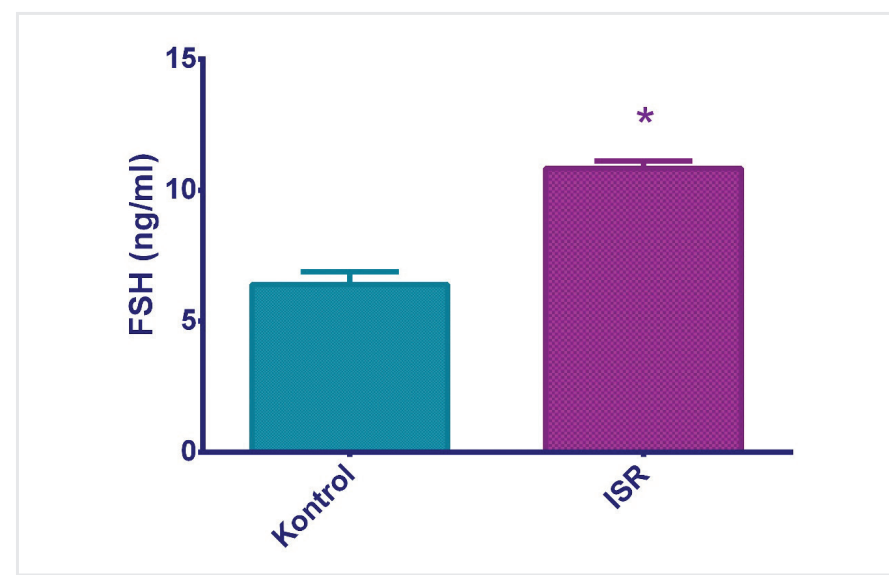

Figure 2. Average FSH levels of experimental groups are shown ( ${ }^{*} p<0.05$, ISR: isotretinoin)

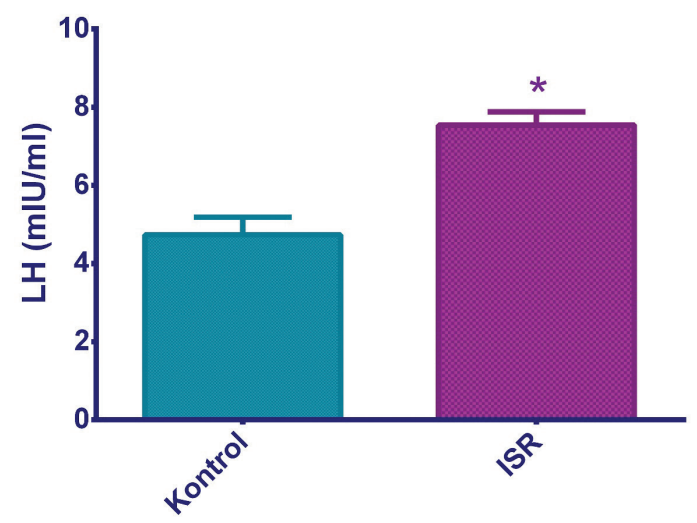

Figure 3. Average LH levels of experimental groups аге shown ( ${ }^{*} p<0.05$, ISR: isotretinoin)

\section{Discussion}

Spermatogenesis that occurs in testicle tubules together with puberty is the event that spermatogonia divide and differentiate and form spermatids $(1,18)$. Endocrine control of spermatogenesis takes place through hormones synthesized from Sertoli and Leydig cells, which are somatic cells of testis, and gonadotropins and steroids. It has been noted that these cells have retinoic acid receptors and Vitamin $\mathrm{A}$ has an agonistic effect in their activation $(7,11,12)$. FSH, LH and testosterone hormones have direct and indirect effects on spermatogenesis that takes place by meiosis (6). While FSH is necessary for stimulating spermatogenesis, testosterone is functional in maintenance (7). In order for testosterone to function, it must be stimulated by LH $(1,6)$. Vitamin A and its metabolite retinoic acid are very critical for spermatogenesis $(13,14,18)$. In the studies investigating the effects of vitamin A and its metabolites on spermatogenesis, highly controversial data have been revealed.

Vitamin A is very important for the production of spermatozoa. In its deficiency, it has been observed that germ cells degenerate, testosterone is under-synthesized and spermatogenesis stops (1922). On the contrary, high doses have also been shown to be teratogenic, reduce testicular mass, disrupt the usual process of spermatogenesis and adversely affect Leydig cells $(5,15,16,23)$. In addition, it was observed that spermatogenesis was normal and was not different compared with the control groups after an 8 -week experiment in rats administered $40 \mathrm{mg} / \mathrm{kg}$ dose of isotretinoin (24).

In a study, rats fed a diet devoid of vitamin A were found to have a higher FSH level compared to the control group, as well as a decrease in LH and testosterone levels. In the same study, it was revealed that there was no change in FSH levels in the group given vitamin $\mathrm{A}$ at a dose of $1 \mathrm{mg}$ for 60 days, $\mathrm{LH}$ increased, but testosterone remained low (25). These findings are also highly controversial. Although there are no different studies showing that vitamin A deficiency or deprivation has an inducing effect on FSH level, there is no clear scientific explanation for those findings. In another study investigating the effects of retinoic acid on rat Leydig cells in cell culture, retinoic acid was shown to increase testosterone and LH synthesis (26). In our study, it was determined that there was a significant increase in the level of all three hormones in the group we applied isotretinoin at a dose of $40 \mathrm{mg} / \mathrm{kg}$ without any restriction in the diet of the experimental groups $(\mathrm{p}<0.05)$. In a clinical study, it was stated that FSH, LH and testosterone levels did not show any change in patients who received isotretinoin treatment at a dose of $0.5-1 \mathrm{mg} / \mathrm{kg}$ for 6 months compared to the control groups (27). We think that this difference may be due to the genetic variation between the species, the duration and dose of treatment in patients, and the duration and dose of treatment in experimental animals.

\section{Conclusion}

The significant increase in FSH, LH and testosterone levels in the ISR group compared to the control group in our study suggests that isotretinoin induces spermatogenesis. We think that nontoxic doses of isotretinoin may be beneficial for patients who have a low sperm count due to disruptions in the spermatogenesis process and who are at risk of sterility or have sterility.

\section{Ethics}

Ethics Committee Approval: Study methods were approved by Bezmialem Vakıf University Experimental Animals Local Ethics Committee with decision number 2013-237.

\section{Peer-review:}

\section{Authorship Contributions}

Concept: M.K., Design: M.K., Data Collection or Processing: M.K., Analysis or Interpretation: M.K., M.E., Literature Search: M.K., Writing: M.K., M.E.

Conflict of Interest: No conflict of interest was declared by the authors.

Financial Disclosure: The authors declared that this study received no financial support. 


\section{References}

1. Esrefoğlu M. Özel Histoloji, 2. Baskı. İstanbul Tıp Kitapevi; 2016. p. 245-6.

2. Boucheron-Houston C, Canterel-Thouennon L, Lee TL, Baxendale V, Nagrani S, Chan WY, et al. Long-term vitamin A deficiency induces alteration of adult mouse spermatogenesis and spermatogonial differentiation: direct effect on spermatogonial gene expression and indirect effects via somatic cells. J Nutr Biochem 2013;24:1123-35.

3. Blomhoff R, Blomhoff HK. Overview of retinoid metabolism and function. J Neurobiol 2006;66:606-30.

4. Gudas LJ, Wagner JA. Retinoids regulate stem cell differentiation. J Cell Physiol 2011;226:322-30.

5. Lee LM, Leung CY, Tang WW, Choi HL, Leung YC, McCaffery P, et al. A paradoxical teratogenic mechanism for retinoic acid. Proc Natl Acad Sci U S A 2012;109:13668-73.

6. McLachlan RI, Wreford NG, Robertson DM, Krester DM. Hormonal Control of Spermatogenesis. Trends Endocrinol Metab 1995;6:95-101.

7. Hogarth CA, Griswold MD. The key role of vitamin A in spermatogenesis. J Clin Invest 2010;120:956-62.

8. Clagett-Dame M, Knutson D. Vitamin A in reproduction and development. Nutrients 2011;3:385-428.

9. Telettin M, Vernet N, Ghyselinck NB, Mark M. Roles of Retinoic Acid in germcell differentiation. Curr Top Dev Biol 2017;125:191225.

10. Nya-Ngatchou JJ, Arnold SLM, Walsh TJ, Muller CH, Page ST, Isoherranean $\mathrm{N}$, et al. Intratesticular 13-cis retinoic acid is lower in men with abnormal semen analyses: a pilot study. Andrology 2013;1:325-31.

11. Raverdeau M, Gely-Pernot A, Féret B, Dennefeld C, Benoit G, Davidson I, et al. Retinoic acid induces Sertoli cell paracrine signals for spermatogonia differentiation but cell autonomously drives spermatocyte meiosis. Proc Natl Acad Sci U S A 2012;109:16582-7.

12. Gely-Pernot A, Raverdeau M, Teletin M, Vernet N, Féret B, Klopfenstein M, et al. Retinoic acid receptors control spermatogonia cell-fate and induce expression of the SALL4A transcription factor. PLOS Genet 2015;11:e1005501.

13. van Pelt AM, de Rooij DG. Retinoic acid is able to reinitiate spermatogenesis in vitamin A-deficient rats and high replicate doses support the full development of spermatogenic cells. Endocrinology 1991;128:697-704.

14. Chunga SSW, Wolgemutha DJ. Role of retinoid signaling in the regulation of spermatogenesis. Cytogenet Genome Res 2004;105:189-202.
15. Comitato R, Esposito T, Cerbo G, Angelini F, Varriale B, Cardone A. Impairment of spermatogenesis and enhancement of testicular germ cell apoptosis induced by exogenous all-trans-retinoic acid in adult lizard Podarcis sicula. J Exp Zool A Comp Exp Biology 2006;305:288-98.

16. Gençoğlan G, Tosun M. Effects of isotretinoin on spermatogenesis of rats. Cutan Ocul Toxicol 2010;30:55-60.

17. Kumas M, Esrefoglu M, Guler M, Eray M. Protective effects of silymarin against isotretinoin induced liver and kidney injury in mice. Indian J Exp Biol 2018;58:158-63

18. Agrimson KS, Onken J, Mitchell D, Topping TB, ChiariniGarcia H, Hogarth CA, et al. Characterizing the spermatogonial response to retinoic acid during the onset of spermatogenesis and following synchronization in the neonatal mouse testis. Biol Reprod 2016;95:81.

19. van Beek ME, Meistrich ML. Spermatogenesis in retinol-deficient rats maintained on retinoic acid. J Reprod Fertil 1992;94:327-36.

20. Paik J, Haenisch M, Muller CH, Goldstein AS, Arnold S, Isoherranen $\mathrm{N}$, et al. Inhibition of retinoic acid biosynthesis by the bisdichloroacetyldiamine WIN 18,446 markedly suppresses spermatogenesis and alters retinoid metabolism in mice. J Biol Chem 2014;289:15104-17.

21. hung SS, Wang X, Roberts SS, Griffey SM, Reczek PR, Wolgemuth DJ. Oral administration of a retinoic acid receptor antagonist reversibly inhibits spermatogenesis in mice. Endocrinology 2011;152:2492-502.

22. Livera G, Rouiller-Fabre V, Pairault C, Levacher C, Habert R. Regulation and perturbation of testicular functions by vitamin A. Reproduction 2002;124:173-80.

23. Kamm JJ. Toxicology, carcinogenicity, and teratogenicity of some orally administered retinoids. J Am Acad Dermatol 1982;6(4 Pt 2 Suppl):652-9.

24. Kuhlwein A, Schütte B. Light microscopic studies of spermatogenesis in rats following the administration of a high doses of 13-cis-retinoic acid. Z Hautkr 1985;60:245-8.

25. Bartke A. Increased sensitivity of seminal vesicles to testosterone in a mouse strain with low plasma testosterone levels. J Endocrinol 1974;60:145-8.

26. Chaudhary LR, Hutson JC, Stocco DM. Effect of retinol and retinoic acid on testosterone production by rat Leydig cells in primary culture. Biochem Biophys Res Commun 1989;158:400-6.

27. Çinar L, Kartal D, Ergin C, Aksoy H, Karadag MA, Aydin T, et al. The effect of systemic isotretinoin on male fertility. Cutan Ocul Toxicol 2016;25:296-9. 